\title{
Impact of Bricolage on Organizational Innovation Through Recognition of Opportunities
}

\author{
Shoaib Ali (Corresponding Author) \\ School of Management, Jiangsu University, Zhenjiang 212013, China \\ Tel: +8618651289296 \\ E-mail: Shooaibali6@gmail.com
}

Farooq Azam (Co-author)

Faculty of Commerce, Hailey College of Commerce, University of the Punjab, Lahore, Pakistan.

Tel: +923334331313

E-mail: lukeblcu@hotmail.com

\begin{abstract}
Hafiz Muhammad Naveed (Co-author)
School of Finance and Economics, Jiangsu University 301 Xuefu Road, Zhenjiang, Jiangsu Province, China

Tel: +8618651289309

E-mail: Hafiznaveed778@gmail.com
\end{abstract}

Muneeba Qayyum (Co-author)

Federal Urdu University of Arts Science and Technology, Islamabad, Pakistan.

Tel: +92 3145230847

E-mail: muneebaqayyum9@gmail.com

Naveed Ahmed (Co-author)

School of Management, Jiangsu University, Zhenjiang 212013, China 
Tel: +923225173103

E-mail: scholar.naveed@yahoo.com

Received: Aug. 14, 2020 Accepted: Sep. 3, 2020 Published: Sep. 25, 2020

doi:10.5296/bms.v11i2.17739 URL: https://doi.org/10.5296/bms.v11i2.17739

\begin{abstract}
Although several studies have presented bricolage as a method in the context of new projects to address resource limitations, none have specifically explored the effects of bricolage to find potential on organizational innovation prospects within the context of recognition of opportunity. The purpose of this research is to identify how the bricolage effect on organization innovation through the recognition of opportunities. The prior study was adopted a causal and comparative design of a quantitative approach while a cross-sectional survey technique is determined to gather data by questionnaire. A simple random sampling technique is adopted to select 242 employees of various Chinese organizations who are working in Pakistan. Descriptive statistics, Pearson correlation, ANOVA, and simple linear regression is regressed to analyze the data through inferential statistical techniques. The results of the study showed there is no substantial change of bricolage on organizational innovation by recognition of opportunities based on the number of staff, year of initiation, and position of the employee. However, it is suggested that organizations should hold training and conferences to raise awareness among workers about the recognition of opportunities and their benefits. This study could be useful to decision-makers, Chinese, and resident investors who plan to invest in Pakistan. Investors can take benefit from understanding the local economy and organization innovation by recognition of opportunities.
\end{abstract}

Keywords: bricolage, organizational innovation, opportunity recognition

\title{
1. Introduction
}

Bricolage described as "making reuse and recombination of whatever is at hand", Lévi-Strauss (1966) was introduced successfully and then progressed in the entrepreneurial activities sector (Baker et al., 2003). This technique was used to design the process and define the experiment to overcome problems in situations. Bricolage makes world use of the situation as distinct (Paul, 2005). While new companies usually lack sufficient resources, bricolage encourages them to endure and succeed by rejoining and reprocessing the resources which fills the specific identified gaps and solve the observed issues. The environments and procedures show novel uses and technical applications. Bricolage helps in-house people to use known methods and techniques at hand to solve creative challenges. Furthermore, evidences suggest that new companies involved in bricolage can address limited resources 
effectively and produce higher performance (An et al., 2018a; Baker \& Nelson, 2005; Cunha et al., 2014; Di Domenico et al., 2010; Senyard et al., 2014).

Bricolage could be seen as creating new possibilities through the use of different available resources (Burgers et al., 2014). There are not only adequate opportunities, there is a need to make appropriate use of them (Desa, 2012). Bricolage became the factor for identifying new opportunities in an organization's innovation circumstance, while entrepreneurship can be another procedure that is also considered significant to enhance the process of identifying opportunities (Van Burg et al., 2012). The bricolage impact is more than just addressing limited resources. Many experts have currently started to examine other bricolage effects, especially the bricolage effects in producing new knowledge. Other research indicated that bricolage would generate new knowledge by overlapping established concurrent stocks of knowledge (Boxenbaum \& Rouleau, 2011). The knowledge produced by bricolage not only breaks the leverage of the resources but also encourages companies to be innovative and creative (Andersen, 2008; Gilbert, 2005).

This gratitude for the function of bricolage developing new facts which demonstrate two important constraints on the impact of bricolage on innovation that prior studied has provided. First, existing research provides higher consideration to the influence of bricolage in leveraging prospects by overcoming source limitations, but by identifying development ways, it neglects the implications of bricolage in recognition of new opportunities. Baker \& Nelson (2005) explained the definition of bricolage "Building new challenges and opportunities by implementing combinations of resources at hand." This description indicates that prospects have been found already, but organizations require more resources to maximize them. Much prevailing research move to support this interpretation and hypothesize bricolage as merely an informal issue-resolving action designed to overcome limited resources by doing that through the opportunities of resources (Baker et al., 2003; Desa, 2012). Bricolage may also allow companies to recognize more opportunities by creating new information, thereby encouraging the recognition of opportunities, another essential process of innovation (Van Burg et al., 2012). However, in the current literature, the influence of bricolage on the recognition of opportunities is rarely addressed.

Second, though comprehensive work has been carried out into the effects of bricolage in the sense of individual entrepreneurial enterprises (Cunha et al., 2014; Senyard et al., 2009, 2014). Few of them established the effect of bricolage on the new entrants of enterprises. The prevalence of infrastructure projects as a study environment as new undertakings is understandable, frequently insufficient of funds, and suitable scenarios for examining the bricolage results in addressing limited resources (Baker \& Nelson, 2005; Senyard et al., 2014). While these studies are intuitive, we could contend that their limited emphasis on bricolage source substantial function in the original undertaking and setting of misunderstands the bricolage effectiveness. Lévi-Strauss (1966) argued that bricolage could also perform external new endeavor frames and developing ideas using available resources. We explore bricolage may provide further benefits to the organizations (e.g., incumbent 
corporations) while examining its effects on knowledge development. For incumbent companies which are more vulnerable to resource stagnation and the new knowledge of available resources created by bricolage that allow them to recognize more opportunities (Gilbert, 2005). This could affect organizational innovation regarding managing new business-wide activities that revelation hubs and exploration of new prospects through entrepreneurial activities, such as business growth and innovation strategies (Stevenson \& Jarillo, 2007; Zahra, 1993). However, according to our best knowledge limited research has identified the impact of bricolage on incumbents organizations (Andersen, 2008; Burgers et al., 2014).

To address the two limitations, we reach beyond the traditional bricolage outcomes of exploiting incentives and examine bricolage's effect on organizational innovation by recognition of opportunities. Bricolage may open new possibilities by fascinating parallel opportunities that already exist. The knowledge generated by bricolage is used not only to achieve the specified objective of accomplishment but also to eliminate the potential that someone faces in the direction of completion. (Ostrom et al., 2015). This sort of recognition of bricolage is not only to resource bricolage but also about finding out the opportunity's recognition for organizational innovation. Because prior researches focused solely on bricolage as on the development of potentials by highlighting the resource limitations they experience and seeking new and innovative opportunities.

There is minimal literature available to address the impact of bricolage on organizational innovation and opportunities (Cunha et al., 2014). A body of work on the effect of bricolage on entrepreneurial practices has started over the past several years. The researcher did not find any work undertaken on bricolage's effect on organizational innovation as recognition of opportunity in Pakistan.

Consequently, our goal is to investigate the effect of bricolage on innovation in organizations by identifying opportunities in the literature to address the gap. Our intend is to create some contribution to the current literature. Firstly, we increase awareness of the purposes that bricolage acts in the development of organizational innovation. Conventional bricolage collection usually hypothesizes bricolage as an emergency issue-resolving action to resolve limited resources. Secondly, our research incorporates prior study by revealing the effectiveness of bricolage in light of existing companies. Earlier studies mainly concentrate on the background of new projects where resources are usually limited (Burgers et al., 2014). Finally, this work tries to insist that bricolage may also encourage the recognition of opportunities in established firms, which is far less likely to ignore capital than new ones.

\subsection{Objectives of the Paper}

1. Examine the effects of bricolage on the organization's innovation along with recognition of opportunity. 


\section{Macrothink}

2. Check the difference in employee attitudes on bricolage and innovation in the organization by recognizing opportunities based on the number of staff, years of initiation, and position of the employee.

The paper is handled as well. In chapter 2, we indicate a theoretical investigation for the support of bricolage impact on organizational innovation and managed factual hypotheses to examine. Chapter 3, organized to the explanation of the target population and description of the sample of data that is taken in this research. Chapter 4, results, and discussion are elaborated after the regression of data. In the end, chapter 5 explain our research conclusion and discussion with the recommendation and future research.

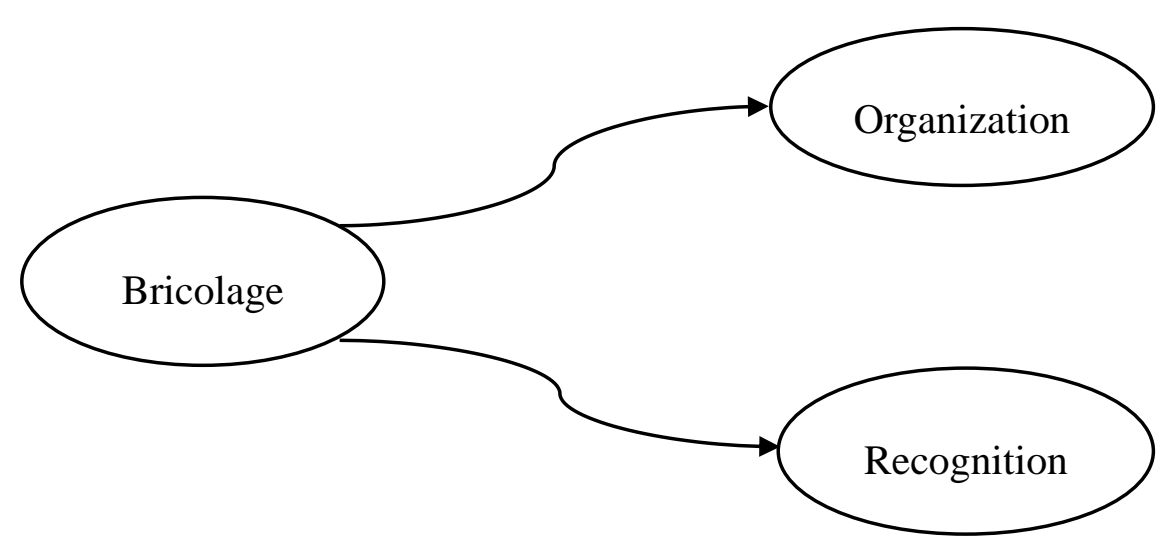

Figure 1: Conceptual Framework

\section{Source: Author}

\section{Review of Literature}

\subsection{Bricolage in the Context of Mythological Thought}

It is a process of mythological consideration and opposes to innovative thought. Mythical justification is to reuse prevailing funds to determine various issues. Morrissey (2003) spreads this expression with every argument: "When one decides to call bricolage the essential of stealing one 's concept from the text of mythology which is less or more messed up or consistent, it should be assumed that each discussion is bricolage". Deleuze \& Guattari (1980) identify bricolage as a descriptive form of production of the deranged creator whereas Rapport (2014) assumed such a bricolage as tickling along with diverse social aspects to generate and drive innovation slightly new or more adequate for perseverance. According to Phillimore et al., (2016) bricolage as poor construction, do-it-yourself, playing and initiatives performed at a minimal stage. It is also performed as mass production having to apply agreements of resource management (Baker \& Nelson, 2005). 
Since the time of new formation, bricolage has indeed been extended to a variety of perspectives and data including philosophical anthropology (Denzin \& Lincoln, 2005; Weinstein \& Weinstein, 1991) and qualitative approaches (Kincheloe, 2005); studies on women (Kelly, 1982), Interactive joint ventures (Conville, 1997), research of the social group, and successful cultural identity (Hebdige, 1995) composite knowledge schemes design and institution building (Lanzara, 1999), explanations of the prominent training program (Dent \& Hatton, 1996; Hatton, 1989; Rynes \& Trank, 1999), lawmaking (Hull, 1997; Tushnet, 1999), evolutionary heredities, economics, and biology (Boxenbaum \& Rouleau, 2011; Campbell, 1997; Hirabayashi \& Kasai, 1993; Lavorgna et al., 2001).

Bricolage is being used to characterize the concept of market structure in the context of entrepreneurship and growing firms (Baker et al., 2003; Baker \& Nelson, 2005). Bricolage describes how heavy-bodied strategies can even be formulated to strengthen literature in an uncertain environment (Paul, 2005; Senyard et al., 2009). The use of the bricolage started to increase more around than in cognitive processes, alongside concepts including entrepreneurship and innovation that have increasingly influenced public discourse and policy planning initiatives in the last century. However, one explanation for its prevalence, especially in community strategy management, that had been historically perceived in the majority of cases. (Weinstein \& Weinstein, 1991).

\subsection{Bricolage Entrepreneurship}

Bricolage is a fairly revolutionary idea in the literature on entrepreneurship and needs further growth. A predecessor to these ideas was credited to Rice \& Rogers (1980) and Fisher (1995) those who focus on the recombination, transmission, and remaking of resources which they believe could be intentional innovative methods. All of this research dealing with the development of economic resources in surrounding (Baker \& Nelson, 2005). The initiatives of entrepreneurship bricolage recognize the upsetting boundaries which maintain the connection between bricolage behavior and the company's advancement with appreciation to evaluate or impose. Bricolage acts that allow organizations to overcome resource constraints, and they may still lock the organization in to strengthen the sequence of actions that increase proficiency. Baker \& Nelson (2005) recognize two parallel and selective forms of bricolage.

Organizations engaged in parallel bricolage and continue with specific tools that are not usually considered for utilization by others which creates a new opportunity. It is not often within the relationships of situation management and institutional, expending unprofessional or self-educated expertise, and connecting consumers and contractors in routines (Baker \& Nelson, 2005).

Therefore, selective bricolage deals with those organizations that used parallel bricolage at the same time, withdrawing it at a later stage until accepted or achieved by the organization. Parallel bricolage organizations cannot be established while organizations that adopt bricolage scarcely suffer from resource limitations but the system is abandoned as resources become accessible (Baker \& Nelson, 2005). Therefore, especially they examine bricolage is 
not just round the addition of resources, specifically, it's a method of approaching opportunities and obstacles, supported by the related body of knowledge and perception of others. They present the concept which even under surface bricoleurs would have to work as their techniques and maybe somewhat uncommon.

\subsection{Organizational Bricolage}

Spicer \& Davis (2014) extended bricolage theory in institutions by claiming that it is a fairly random operation that implies subject to constraints. They also claimed that an organizational interest is limited to it. Organizational bricolage is defined as a process by which an innovative organization is established by the depiction of organizational processes to be handed in a specific situation. Performative funds are realized as important primarily as a scarcity of funds and existing principles sometimes restrict the bricolage process. Sehring (2009) realized bricolage in a firm sense as placed amid pathway dependence and growth in existing and substitute pathway, that is not ever entirely innovative as need necessities and new thoughts.

In the organizational behavior literature, there is a fundamental presumption about bricolage which is incontestably helpful and contributes to development. Nonetheless, it is a minor debate about whatever may seem like successful bricolage and even less conversation about how to identify or calculate productive bricolage. One significant exception seems to be, Weick (2001) who seeks to suggest what bricolage appears successful. Rupp et al., (2006) recognizes guidance on how bricolage should be promoted and who is trying to determine bricolage effectiveness. So, this concept of what exactly bricolage appears like, and what the boundaries are, seems to be under dispute.

From recent papers, a specific criticism has appeared that prior work did not investigate conceptual or situational tools as part of the bricolage system. Some also don't deal with bricolage's political essence as a method to arouse change. The unintended and potentially undesirable effects of bricolage are often barely investigated. So, no efforts to define the boundaries of bricolage as a term seem to be produced yet.

\subsection{Opportunity and Development}

In general terms, an opportunity satisfy a business need that may be an ability to give superior value through an innovative mix of resources (BRUNK et al., 1987; Kirzner, 1997; Veciana, 2007). Though "opportunities" identify a variety of aspects that start unformed and grow more over time.

Unused or unemployed capital, as well as emerging skills or technology, that provide opportunities to build and produce new value for prospective customers, it may indefinitely be the exact forms that will take on a new value. For instance, the technology for creating a material that combines the qualities of both metal and glass can be produced before established applications exist; new medicinal compounds can be generated without understanding the conditions under which the applications would be successful. Therefore, 
opportunities resulting from underused or unemployed capital, from technology or other forms of innovative information or skills can be classified as capabilities for value creation (Schroeder et al., 1996).

Opportunities start as basic concepts that get more complex as entrepreneurs grow them. The process requires a lot of constructive efforts like the production of new products, the creation process here gives rise to a whole company, and not just a product (Chesbrough \& Crowther, 2006).

Our role here is departing from previous literature that considers the identification of opportunities to be essentially a process of finding something already established. We consider the development of the opportunity to be a continuous, proactive process that is important for the synthesis of a company (Kirzner, 1997).

In short, we develop a structure that links and comprise of bricolage, organizational innovation, and recognition of opportunity. In the following, we will elaborate on organizational innovation and opportunity recognition as well as their connectivity.

\subsection{Bricolage and Recognition of Opportunity}

When individuals turn basic ideas into full-blown business strategies then prospects grow. But the method of creating opportunities is conceptually different from the recognition or identification of opportunities. What most entrepreneurial literature considers "opportunity recognition"' manages to involve three separate processes: first is measurement or understanding of business demands and/or underemployed capital, second is identifying or finding a "match" between specific consumer needs and defined resources, and third is building of a new "match" in the context of a business model between previously separate needs and requirements (De Koning \& Muzyka, 1999; Hills, 1995). These pathways reflect awareness, exploration, and development respectively-not just "recognition" (Christensen et al., 1990; Conway \& McGuinness*, 1986; Singh et al., 1999).

An "opportunity" which fails to pass via a "gate" successfully to the respective level of development or application may be changed or even aborted. Resource and competition assessment also contribute to valuable business idea revisions. At almost the same time, evaluation techniques have the impact of conceiving several prospects at any of many developmental stages. Generally, the term "recognition" conveys a decision which specifies whether a development opportunity will obtain the resources to develop toward the next level. Inside the literature, on system creation, this is called the judgment summative (Phillips, 2016).

Unusual experience and understand exactly-how resulting as bricolage is critical for the companies to recognize market prospects (Foss et al., 2008). There is an effect of previous understanding on the recognition of opportunities was well identified in current literature (Arentz et al., 2013; Gruber et al., 2012; Shane, 2000; Ucbasaran et al., 2009). As a personalized knowledge and collaboration process, bricolage provides a particular 
understanding of the facilities that the means of an organization can offer and produces fresh insights into how various information elements can be integrated to develop new products and services (Boxenbaum \& Rouleau, 2011; Cunha et al., 2014).

In particular, bricolage makes a significant contribution to recognizing the opportunities of incumbent organizations in dualistic different ways. Firstly, bricolage encourages the incumbent organizations to particular up with a great opportunity. Therefore, via creativity judgment and understanding which helps companies through bricolage to generate non-theoretical, experience-based knowledge. Secondly, bricolage enables companies to make a more interconnected opportunity. Due to its inherent limitation, trial-and-error, and regionally emerging attributes, bricolage almost always produces evaluative, unforeseen, tacit, difficult-to-imitate knowledge, and competitive cost services (Duymedjian \& Rüling, 2010). Moreover, the increase in ways of recombining and evaluating knowledge storage empowers companies to develop more diverse opportunities.

However, the evaluative information acquired by bricolage also transforms the unusual cognitive frameworks and trends of companies, that further enables companies to develop interdependent opportunities (Baron, 1998). In short, most of the time, firms using bricolage seem to be more likely to understand not only a wider variety of opportunities as well as a more diverse variety of opportunities. Thus, we consider:

\section{H1: Bricolage and recognition of the opportunities have a positive association.}

\subsection{Bricolage and Organizational Innovation}

Organizations often impress by discovering ways to operate competitively given resource limitations, as they figure out how to make the limited resources available to them more efficient (Johns \& Hogan, 1961). Resource-Based View (RBV) determines the types of resources that enable businesses to achieve an economical edge in the marketplace (Hooi et al., 2016; Sivathanu \& Pillai, 2019). In addition to this, RBV focusses so much on building a competitive edge in a responsible way across the capital (Eisenhardt, K.M. \& Martin, 2000).

The source of competitive advantage lies in the ability of an organization to adapt rapidly to the changing world through the mechanisms of innovation. Innovation can be distinct as a firm's implementation of a new concept or action (Damanpour \& Gopalakrishnan, 1998). The aspect of the strategic decision-making mechanism collateralized communication is drawn from the literature of organizational culture which is nearly associated with the internal situation of the organization to encourage creativity and the commitment to innovation (Miller, 1987). However, it can be defined as the innovation and creativity of the business, which is correlated with the exposure to new ideas and possibilities as a cultural element of businesses trying to innovate.

Business awareness and internal organizational analyses that discuss how companies are adjusting to their environment and how they are creating a competitive edge (Hurley \& Hult, 1998). In this study, we found that a stronger capacity for transformation and creativity is 
correlated with a higher degree of innovativeness in the structure of the company. Greater rates of innovation and creativity are also related to cultures that prioritize learning, growth, and integrated decision-making.

Hence, organizational innovation can be characterized as the receptiveness to innovations as an integral feature of the organization's growth as well as a function of organizational orientation to build creativity (Calantone et al., 2003). In certain terms, innovation is often seen as the demand for better company's innovation and the capacity to adjust as the company evolves and learns and those improvements can also be brought about and creativity and organizational effectiveness (Hurley \& Hult, 1998).

Organizational innovativeness is often defined as powerful and supporting innovation in terms of the creation of new goods or methods, entering a new market, or creating new key strategies (Wang \& Ahmed, 2004). They also stated that five domains are commonly defined in the literature on organizational innovation, taking into consideration the organizational capabilities to innovate, including product innovation, business innovation, process innovation, behavioral innovation, and strategic innovation. However, In our research, as we analyze the bricolage impact on organizational innovation which covers by the innovativeness circle by Wang \& Ahmed (2004), it seems to be a more effective organizational innovation.

\section{H2: Bricolage and organizational innovation have a positive association.}

Bricolage helps to identify numerous opportunities and its literature enables us to gather information, usage, and understanding that could promote organizations how to generate novel means by combining existing reserves to explain new challenges inside restricted chances and sources (Cunha et al., 2014; Foss et al., 2008). However, in these situations, here is a good chance to recognize opportunities to give an organization a better path of progress. So, bricolage is a good design for fresh business because it fosters original prospects through recognition of the opportunities.

\section{Methodology Design}

\subsection{Sample and Data Collection}

To test the analysis of our hypothesis, we gathered data throughout the questionnaire from Chinese companies that are registered and working in Pakistan and it is a developing country that is facing economic crises. To endure and maintain a dynamic environment, an organization must not only achieve their surviving abilities but also generate new aptitudes through recognition of opportunity activities and circumstances to analyze our hypothesis.

The questionnaire was created based on observations from earlier research which showed good reliability and validity (An et al., 2018b; Burgers et al., 2014; Calantone et al., 2003; Ma et al., 2011; Yiu et al., 2007). An English version of the questionnaire was first established for our understanding. Two interpreters then separately converted the English version into Chinese, as well as the Chinese version ahead-translated into English. To make 
sure theoretical uniformity the translation and back-translation procedure was managed two times. We checked the questionnaire by examining employees in five companies to improve understandability and validities. We questioned them to confirm the questionnaire's significance and interpretation. Until we properly gathered data, we made small changes relying on their recommendations. The systematic collection of data proceeded approximately for 10 months, from November 2018 to August 2019. We were targeted especially top managers, middle managers, and lower managers. We used the members' list which is mentioned in the Pakistan-China Joint Chamber of Commerce \& Industry (PCJCCI) [1] to create a random list of 700 firms. However, to raise the response rate, we agreed to make a detailed analysis report available to the participants. From total we were received 265 feedback but, 23 incomplete questionnaires were omitted. The final sample comprised 242 valid questionnaires, contributing a 24.2 percent response rate.

\section{Results and Discussions}

\subsection{Demographic Construction of Respondents}

Table 1. Demographic construction of respondents

\begin{tabular}{llll}
\hline Demographic variables & & $\mathrm{F}$ & $\%$ \\
\hline Staff & Below 50 & 67 & 27.6 \\
& $51-100$ & 98 & 40.4 \\
\multirow{3}{*}{ Years of initiation } & Above than 100 & 89 & 36.7 \\
& Less than 50 year & 195 & 80.5 \\
& $51-100$ & 51 & 21.0 \\
Position of Employees & More than 100 years & 2 & 0.01 \\
& Top managers & 60 & 24.7 \\
& Middle manager & 70 & 28.9 \\
& Lower manager & 65 & 26.8 \\
& Non-managerial staff & 63 & 26.03 \\
\hline
\end{tabular}

Source: Author

F, Frequency

Table 1, reveals that 27.6 percent of companies had below 50 workers, while 40.4 percent of companies had 51-100 workers, 36.7 percent of companies employed extra as 100. 80.5 percent belonged to the classification of newly formed organizations since they worked for below period than 50 years; Although 21.0 percent presented workers who worked from 51 to 100 years and only 0.01 percent remained organizations over 100 years old. 24.7 percent of respondents worked like senior supervisors, 28.9 percent worked as middle managers, 26.8 percent worked as lower managers and 26.03 percent worked as non-managers. 


\subsection{Measurement of Respondents and Descriptive Statistics}

Table 2. Measurement of respondents and descriptive statistics

\begin{tabular}{|c|c|c|c|c|c|c|c|}
\hline $\begin{array}{l}\text { Strongly } \\
\text { Disagree }\end{array}$ & Disagree & Neither & Agree & $\begin{array}{l}\text { Strongly } \\
\text { Agree }\end{array}$ & $\mathrm{N}$ & Mean & SD \\
\hline \multicolumn{8}{|c|}{ Trust in the capabilities to solve new challenges } \\
\hline 12 & 8 & 7 & 149 & 66 & 242 & 4.02 & .940 \\
\hline \multicolumn{8}{|c|}{ Taking up challenges with current sources than others } \\
\hline 5 & 11 & 17 & 156 & 53 & 242 & 3.99 & .811 \\
\hline \multicolumn{8}{|c|}{ Application of current tools to address a critical question } \\
\hline 9 & 18 & 17 & 150 & 48 & 242 & 3.86 & .941 \\
\hline \multicolumn{8}{|c|}{ Addressing emerging problems by maximizing existing tools } \\
\hline & 6 & 22 & 131 & 64 & 242 & 3.88 & 1.074 \\
\hline \multicolumn{8}{|c|}{ Development of a satisfactory alternative to new challenges } \\
\hline 8 & 17 & 3 & 116 & 98 & 242 & 4.15 & .989 \\
\hline \multicolumn{8}{|c|}{ Trying to combine available resources and astonishing new problems } \\
\hline 11 & 5 & 20 & 139 & 67 & 242 & 4.01 & .924 \\
\hline \multicolumn{8}{|c|}{ New issues, practical solutions and the resources we have } \\
\hline 7 & 14 & 19 & 116 & 96 & 242 & 4.20 & .875 \\
\hline \multicolumn{8}{|c|}{ Company in the market to address additional challenges } \\
\hline 18 & 20 & 16 & 113 & 75 & 242 & 3.85 & 1.167 \\
\hline \multicolumn{8}{|c|}{ Regularly scheduled practices and innovative faces at potential } \\
\hline & 8 & 20 & 126 & 76 & 242 & 4.00 & 1.006 \\
\hline \multicolumn{8}{|c|}{ Starting to feel sensitive to new opportunities } \\
\hline 6 & 13 & 13 & 141 & 69 & 242 & 4.05 & .882 \\
\hline \multicolumn{8}{|c|}{ New potential opportunities available } \\
\hline 15 & 26 & 24 & 122 & 55 & 242 & 3.72 & 1.115 \\
\hline \multicolumn{8}{|c|}{ Product-oriented, cutting-edge technology development } \\
\hline 17 & 15 & 34 & 107 & 69 & 242 & 3.80 & 1.129 \\
\hline \multicolumn{8}{|c|}{ Attempting to cut-edge $R \& D$ based on process development } \\
\hline & & & 106 & 64 & 242 & 3.80 & 1.031 \\
\hline \multicolumn{8}{|c|}{ Multinational level of professional services of $R \& D$} \\
\hline & 20 & 39 & 106 & 60 & 242 & 3.71 & 1.137 \\
\hline \multicolumn{8}{|c|}{ Original various goods and services business } \\
\hline & 13 & 25 & 118 & 76 & 242 & 3.98 & 1.004 \\
\hline \multicolumn{8}{|c|}{ Industrial growth and operational excellence } \\
\hline & 20 & 34 & 124 & 54 & 242 & 3.79 & 1.013 \\
\hline \multicolumn{8}{|c|}{ Comparative analysis of patent applications with major competitors } \\
\hline 18 & 11 & 42 & 101 & 70 & 242 & 3.80 & 1.131 \\
\hline
\end{tabular}

Source: Author

The viewpoint of the respondents' responses to their power and ability to identify applied results to different opportunities through employing existing sources. while using available facilities, the majority 88.8 percent of participants agreed on their trust in the capabilities to solve new challenges. 8.3 percent disagree with the assertion, while 2.9 percent of participants retained on either. While the average of them is 4.02. A view of the participants of Taking up challenges with current sources than others. it is identified that the majority of 86.3 percent of people decided that they would happy to take up the challenge. Even so, 5.7 percent disagreed as assertion while 7.2 percent stayed neutral. The average is 3.88 . The understanding of the participants about the application of current tools to address a critical question. It examined that $81.7 \%$ of responders decided to use an existing tool in response to new issues. However, 11.2 percent strongly disagree as mentioned, although 7.2 percent stayed unchanged on either. The average value is 3.86 . 
The impression of the participants of how they address emerging problems by maximizing existing tools. The majority of 80.5 percent of respondents decided to address new problems that they've had to encounter. While 10.4 percent, however, disagreed with the assertion, and 9.1 percent of respondents stuck on neither. The average is 3.88. The participants' assumptions of how they consider the development of a satisfactory alternative to new challenges. The majority of 88.3 percent of people decided to develop solutions that can solve new issues. 10.4 percent on the other hand disagreed as assertion whereas 1.1 percent stayed neutral.

We are trying to combine available resources and astonishing new problems. The majority of 85.1 percent of the respondents accepted that we are taking on a remarkable range of new problems. 6.7 percent disagreed with the assertion though 8.3 percent of people stayed on neither. The respondents about new issues, practical solutions, and the resources we discovered by a questionnaire that most of 87.6 percent acknowledged. Nevertheless, 4.6 percent disagreed with the argument and 7.9 percent of people did not agree with that either. The thinking of workers about the company in the market to address additional challenges. It saw 77.6 percent of participants decided to align resources to address new challenges. Even so, 15.8 percent of respondents disagreed whilst still 6.6 percent of participants stayed on neither. Interpretation of the participants about regularly scheduled practices and innovative faces at the potential. It is seen that 83.0 percent of respondents decided to generate possible innovative ideas for their everyday routines. On the other side, 8.7 percent disagreed with the comment while being on neither stayed 8.3 percent of people.

View of the participants about starting to feel sensitive to new opportunities. It is seen that a majority of 86.7 percent of the respondents accepted the unique wakefulness or openness to new opportunities. However, 7.9 percent disagreed with the claim, thus 5.4 percent of respondents kept on neither. Thinking of the respondent about new potential opportunities available. 73.0 percent of respondents decided because seeing possible new opportunities comes to everybody quite simply. Nonetheless, 17.0 percent disagreed with the premise while 10.0 percent of people held with either.

Product-oriented, state-of-the-art technology growth suggests that the majority of 72.6 percent of employees have recognized that they have invested entirely in product-oriented innovation. Nonetheless, 13.3 percent disagreed with the result, even though 14.1 percent of respondents did not stay on either. The view of the participants about attempting to cut-edge R\&D based on process development. It is shown 70.1 percent of workers did agree that fully involved in cutting-edge research and development based on process technology. Additionally, 14.5 percent disagreed with the comment though 15.4 percent focused on neither. The understanding of the participants' multinational level of professional services of R\&D. Most of 68.6 percent agreed to maintain high R\&D capabilities. Hence, 15.5 percent are not agreed with the statement, while 16.2 percent of participants focused on neither.

However, an expectation of the participants about the original various goods and services business. The majority of 80.1 percent of people believed that organization has launched 
several innovative products and services. Additionally, 9.5 percent disagreed with the argument while 10.4 percent stayed on neither. And also, the opinion of the responders about Industrial growth and operational excellence. The majority of 73.5 percent of respondents decided to promote the production of revolutionary technologies in their business. From the other side, 12.4 percent disagreed with the argument while 14.2 percent are not agreed.

In the end, the view of the responders about comparative analysis of patent applications with major competitors. The majority of 70.5 percent of workers decided that they obtained further patents as like biggest competitors. Nevertheless, 12.2 percent are not agreed with the claim while 17.5 percent are not agreed either.

\subsection{One-Way ANOVA}

It is created by statistician Ronald Fisher, analysis of variance (ANOVA) is a set of statistical methods and their related estimation techniques (including the "variation" among as well as between groups) being used to evaluate group mean variations in a sample (Buckless \& Ravenscroft, 1990). One-way ANOVA is built on a statistical standard which explains the effects expected to determine the significance of any particular observation:

$$
Y i j=\mu+\alpha i+\varepsilon i j
$$

Where,

Yij $=$ is the observed value,

$\mu=$ is the combination of the population mean,

$\alpha=$ fixed deviation of the mean of the group,

$\varepsilon \mathrm{ij}=$ random error effect.

4.4 One-Way ANOVA Based on the Number of Staff with the Questionnaire

Table 3. One-way ANOVA based on the number of staff with the questionnaire

\begin{tabular}{llccccc}
\hline Number of staff & & SS & df & MS & F & Sig. \\
\hline Below 50 & Between Groups & 330.529 & 2 & 165.264 & 1.530 & .239 \\
51-100 & Within Groups & 25912.131 & 240 & 107.9672 & & \\
more than 100 & Total & 26242.661 & 242 & & & \\
\hline
\end{tabular}

Source: Author SS; the sum of the square, df; a degree of freedom, MS; mean of the square

The findings of one-way ANOVA suggest there is no substantial change in bricolage that is identified in organizational innovation along with recognition of opportunities based on the number of staff employed inside a company. 


\section{Macrothink}

4.5 One-Way ANOVA Based on Years of Initiation with the Questionnaire

Table 4. One-way ANOVA based on years of initiation with the questionnaire

\begin{tabular}{llccccc}
\hline $\begin{array}{l}\text { Years of } \\
\text { initiation }\end{array}$ & & SS & df & MS & F & Sig. \\
\hline Less than 50 & Between Groups & 250.157 & 2 & 125.078 & 1.154 & .329 \\
$51-100$ & Within Groups & 25992.613 & 240 & 108.302 & & \\
More than 100 & Total & 26242.661 & 242 & & & \\
\hline
\end{tabular}

Source: Author

The findings with one-way ANOVA demonstrated that no important difference is observed in bricolage on organizational innovation through recognition of opportunities based on years of initiation of the organization.

4.6 One-Way ANOVA Based on the Position of Employees with A Questionnaire

Table 5. One-way ANOVA based on the position of employees with a questionnaire

\begin{tabular}{llll|lll}
\hline $\begin{array}{l}\text { Position of } \\
\text { Employee }\end{array}$ & & & & & \\
\hline Top managers & Between Groups & 476.822 & 3 & 158.940 & 1.474 & .232 \\
Middle manager & Within Groups & 25765.841 & 239 & 107.806 & & \\
Lower manager & Total & 26242.661 & 242 & & & \\
Non-managerial & & & & & & \\
staff & & & & & & \\
\hline
\end{tabular}

Source: Author

Analysis with one-way ANOVA, bricolage observed that there is no substantial variation in organizational innovation by recognizing opportunities based on employee position within the organization.

\subsection{Correlation Matrix}

4.7.1 Correlation Matrix

Table 6. Correlation matrix

\begin{tabular}{llll}
\hline & Bricolage & $\begin{array}{l}\text { Recognition } \\
\text { opportunity }\end{array}$ & $\begin{array}{c}\text { Organizational } \\
\text { innovation }\end{array}$ \\
\hline Bricolage & 1 & $.622^{* *}$ & $.530^{* *}$ \\
Recognition opportunity & $.622^{* *}$ & 1 & $.620^{* *}$ \\
Organizational innovation & $.530^{* *}$ & $.620^{* *}$ & 1 \\
\hline
\end{tabular}




\section{Macrothink Institute ${ }^{\mathrm{TM}}$}

Bricolage is strongly correlated through opportunities recognition $(\mathrm{r}=.622 * *)$, and it has been identified that this association is extremely important and significantly linked. Bricolage is significantly positively related to innovation of organization $(\mathrm{r}=.530 * *)$, and it has been observed that this association is highly important and optimistic. Recognition of opportunity is directly correlated with bricolage $(\mathrm{r}=.622 * *)$, and it has been noted that this association is significantly essential and significantly associated. Opportunity recognition is strongly correlated with organizational innovation $\left(\mathrm{r}=.620^{* *}\right)$, so it has been reported that this association is extremely important and directly related.

Organizational innovation is connected strongly with bricolage $(\mathrm{r}=.530 * *)$, and this has been discovered that this association is vitally important and directly correlated. Organizational innovation is reasonably correlated with opportunities recognition $(r=.620)$, and this has been observed that this association is extremely important and significantly associated. So, it's determined and outcomes of correlation have shown a positive relationship exists.

\subsection{Regression Analysis}

4.8.1 Analysis of Bricolage, Organizational Innovation, and Recognition of Opportunity

Table 7. Analysis of bricolage, organizational innovation, and recognition of opportunity

\begin{tabular}{lllll}
\hline Variables & $\mathrm{R}$ & $\mathrm{R}^{2}$ & Adjusted $\mathrm{R}^{2}$ & Std. error of the estimate \\
\hline $\begin{array}{l}\text { Bricolage } \\
\text { Recognition of opportunity }\end{array}$ & $.631^{\mathrm{a}}$ & .376 & .373 & .62276 \\
$\begin{array}{l}\text { Bricolage } \\
\text { Organizational innovation }\end{array}$ & $.507^{\mathrm{a}}$ & .287 & .273 & .68701 \\
\hline
\end{tabular}

\section{Source: Author}

The analysis of this table shows that there is a 63 percent association between bricolage and potential identification and there is a small 38 percent difference. There is a 50 percent association between bricolage and innovation in organizations, and there is a 28 percent substantial difference.

\subsubsection{Coefficient}

Table 8. Coefficient

\begin{tabular}{llllll}
\hline Predictors & $\mathrm{b}$ & $\mathrm{SE}$ & $\beta$ & $\mathrm{t}$ & Sig. \\
\hline $\begin{array}{l}\text { Constant } \\
\text { Bricolage } \\
\text { Recognition of opportunity }\end{array}$ & 1.121 & .290 & .633 & 3.801 & .00 \\
$\begin{array}{l}\text { Constant } \\
\text { Bricolage } \\
\text { Organizational innovation }\end{array}$ & .692 & .072 & .537 & 9.580 & .00 \\
\hline
\end{tabular}

Source: Author 
Bricolage $\beta$-value is 0.633 . That means 49 percent describes bricolage and achievement development, at p-value 0.000 . This suggests an important correlation between bricolage and opportunity recognition. A regression model at $\mathrm{p}<0.001$ is important. This shows a strong, important connection of bricolage as opportunity recognition. Bricolage $\beta$-value is 0.537 . While bricolage demonstrates 52.9 percent innovation of organization p-value is 0.000 which is identifying a positive correlation between bricolage and organization innovation. A regression model at $\mathrm{p}<0.001$ is important. It indicates an important positive correlation of bricolage with innovation in organizations.

\section{Conclusion and Discussion}

The bricolage function in the innovation of the organization must not be restrictions of source or reserve but should also be to recognize an awareness of opportunities. The purpose of this paper is to determine the distinction in workplace expectations regarding bricolage and innovation within the organization by recognizing opportunities based on the number of staff, years of initiation, and employee position.

The first finding of the study is that there is a positive significant association between bricolage and organization innovation. These outcomes are reliable as prior research which were managed by (An et al., 2018a; Ardichvili et al., 2003; Gruber et al., 2012; Senyard et al., 2014). They also indicated recognition of opportunity is significantly related to commercial enterprises. When a company finds certain opportunities it also has more possibilities of developing and doing business. Secondly, there is a substantial effect of bricolage by recognition of opportunity. Therefore, according to the third finding of the paper, there is no substantial consistency identified of bricolage on organization innovation on the based-on number of staff, years of initiation, and employees' position in an organization.

\subsection{Recommendations and Future Research}

This is recommended that colleges and universities should arrange workshops and conferences to create attention among students and faculty about bricolage which can be useful in their current environment or we can suggest in their professional careers. Research can also be undertaken using a qualitative methodology to provide an in-depth understanding of the circumstances and criteria that exist. Furthermore, future work may also be used as a longitudinal research design more to investigate complex differences among bricolage, increasing performance, and market entrepreneurial activities.

\section{Acknowledgement}

We are gratified to Professor Sufi Abbas Shah Alamdar and other co-authors for their outstanding involvement and support in this research work.

\section{References}

An, W., Zhao, X., Cao, Z., Zhang, J., \& Liu, H. (2018a). How Bricolage Drives Corporate Entrepreneurship: The Roles of Opportunity Identification and Learning Orientation. Journal 
of Product Innovation Management, 35(1), 49-65. https://doi.org/10.1111/jpim.12377

An, W., Zhao, X., Cao, Z., Zhang, J., \& Liu, H. (2018b). How Bricolage Drives Corporate Entrepreneurship: The Roles of Opportunity Identification and Learning Orientation. Journal of Product Innovation Management, 35(1), 49-65. https://doi.org/10.1111/jpim.12377

Andersen, O. J. (2008). A bottom-up perspective on innovations: Mobilizing knowledge and social capital through innovative processes of bricolage. Administration and Society, 40(1), 54-78. https://doi.org/10.1177/0095399707311775

Ardichvili, A., Cardozo, R., \& Ray, S. (2003). A theory of entrepreneurial opportunity identification and development. Journal of Business Venturing, 18(1), 105-123. https://doi.org/10.1016/S0883-9026(01)00068-4

Arentz, J., Sautet, F., \& Storr, V. (2013). Prior-knowledge and opportunity identification. Small Business Economics, 41(2), 461-478. https://doi.org/10.1007/s11187-012-9437-9

Baker, T., Miner, A. S., \& Eesley, D. T. (2003). Improvising firms: Bricolage, account giving and improvisational competencies in the founding process. Research Policy, 32(2 SPEC.), 255-276. https://doi.org/10.1016/S0048-7333(02)00099-9

Baker, T., \& Nelson, R. E. (2005). Creating something from nothing: Resource construction through entrepreneurial bricolage. Administrative Science Quarterly, 50(3), 329-366. https://doi.org/10.2189/asqu.2005.50.3.329

Baron, R. A. (1998). Cognitive mechanisms in entrepreneurship: Why and when enterpreneurs think differently than other people. Journal of Business Venturing, 13(4), 275-294. https://doi.org/10.1016/S0883-9026(97)00031-1

Boxenbaum, E., \& Rouleau, L. (2011). New knowledge products as bricolage: Metaphors and scripts in organizational theory. Academy of Management Review, 36(2), 272-296. https://doi.org/10.5465/amr.2009.0213

BRUNK, G. G., CALDEIRA, G. A., \& LEWIS-BECK, M. S. (1987). Capitalism, socialism, and democracy: An empirical inquiry. European Journal of Political Research, 15(4), 459-470. https://doi.org/10.1111/j.1475-6765.1987.tb00887.x

Buckless, F. a., \& Ravenscroft, S. P. (1990). Contrast Coding: A Refinement of ANOVA in Behavioral Analysis. The Accounting Review, 65(4), 933.

Burgers, H., Stuetzer, M., \& Senyard, J. M. (2014). Antecedents, Consequences, and the Mediating Role of Bricolage in Corporate Entrepreneurship. Academy of Management Proceedings, 2014(1), 13473-13473. https://doi.org/10.5465/ambpp.2014.13473abstract

Calantone, R., Garcia, R., \& Dröge, C. (2003). The effects of environmental turbulence on new product development strategy planning. Journal of Product Innovation Management, 20(2), 90-103. https://doi.org/10.1111/1540-5885.2002003 
Campbell, D. R. (1997). Genetic correlation between biomass allocation to male and female functions in a natural population of Ipomopsis aggregata. Heredity, 79(6), 606-614. https://doi.org/10.1038/hdy.1997.206

Chesbrough, H., \& Crowther, A. K. (2006). Beyond high tech: Early adopters of open innovation in other industries. $R$ and $D$ Management, 36(3), 229-236. https://doi.org/10.1111/j.1467-9310.2006.00428.x

Christensen, P., Peterson, R., \& Madsen, O. (1990). Opportunity identification: The contribution of entrepreneurship to strategic management. Aarhus: Aarhus University Institute of

Management. https://scholar.google.de/scholar?q=christiansen+Opportunity+Identification\%3A+The+Cont ribution+of+Entrepreneurship+to+Strategic + Management\&btnG $=\& h \mathrm{l}=\mathrm{de} \&$ as_sdt $=0 \% 2 \mathrm{C} 5 \# 0$

Conville, R. L. (1997). Between spearheads: Bricolage and relationships. Journal of Social and Personal Relationships, 14(3), 373-386. https://doi.org/10.1177/0265407597143006

Conway, H. A., \& McGuinness, N. W. (1986). Idea Generation in Technology-Based Firms. Journal of Product Innovation Management, 3(4), 276-291. https://doi.org/10.1111/1540-5885.340276

Cunha, M. P. E., Rego, A., Oliveira, P., Rosado, P., \& Habib, N. (2014). Product innovation in resource-poor environments: Three research streams. Journal of Product Innovation Management, 31(2), 202-210. https://doi.org/10.1111/jpim.12090

Damanpour, F., \& Gopalakrishnan, S. (1998). Theories of organizational structure and innovation adoption: The role of environmental change. Journal of Engineering and Technology Management - $\quad$ JET-M, $\quad 15(1), \quad$ 1-24. https://doi.org/10.1016/S0923-4748(97)00029-5

De Koning, A. J., \& Muzyka, D. F. (1999). Conceptualizing Opportunity Recognition as a Socio-Cognitive Process. In SSE/EFI Working Paper Series in Business Administration No 1999,

http://citeseerx.ist.psu.edu/viewdoc/download?doi=10.1.1.577.4890\&rep=rep1\&type=pdf

Deleuze, G., \& Guattari, F. (1980). Capitalisme et schizophrénie. https://www.wikizero.com/en/Anti-Oedipus

Dent, J. N., \& Hatton, E. (1996). Education and poverty: An Australian primary school case study. Australian Journal of Education, 40(1), 46-64. https://doi.org/10.1177/000494419604000104

Denzin, N. K., \& Lincoln, Y. S. (2005). The Discipline and Practice of Qualitative Research. Journal of Chemical Information and Modeling, 53, 160. https://doi.org/10.1017/CBO9781107415324.004

Desa, G. (2012). Resource Mobilization in International Social Entrepreneurship: Bricolage 
as a Mechanism of Institutional Transformation. Entrepreneurship: Theory and Practice, 36(4), 727-751. https://doi.org/10.1111/j.1540-6520.2010.00430.x

Di Domenico, M. L., Haugh, H., \& Tracey, P. (2010). Social bricolage: Theorizing social value creation in social enterprises. Entrepreneurship: Theory and Practice, 34(4), 681-703. https://doi.org/10.1111/j.1540-6520.2010.00370.x

Duymedjian, R., \& Rüling, C. C. (2010). Towards a foundation of bricolage in organization and management theory. Organization Studies, 31(2), 133-151. https://doi.org/10.1177/0170840609347051

Eisenhardt, K. M., \& Martin, J. A. (2000). Dynamic capabilities: what are they? Strategic Management Journal. https://onlinelibrary.wiley.com/doi/abs/10.1002/1097-0266(200010/11)21:10/11\%3C1105::AI D-SMJ133\%3E3.0.CO;2-E

Fisher, Y. (1995). Fractal Image Compression Theory and Application. In Springer-Verlag. https://doi.org/10.1007/978-1-4612-2472-3

Foss, N. J., Klein, P. G., Kor, Y. Y., \& Mahoney, J. T. (2008). Entrepreneurship, subjectivism, and the resource-based view: toward a new synthesis. Strategic Entrepreneurship Journal, 2(1), 73-94. https://doi.org/10.1002/sej.41

Gilbert, C. G. (2005). Unbundling the structure of inertia: Resource versus routine rigidity. Academy of Management J481-763. https://doi.org/10.5465/AMJ.2005.18803920

Gruber, M., MacMillan, I. C., \& Thompson, J. D. (2012). From Minds to Markets: How Human Capital Endowments Shape Market Opportunity Identification of Technology $\begin{array}{llll}\text { Start-Ups. Journal } \quad \text { of } & \text { Management, } & \text { 38(5), }\end{array}$ https://doi.org/10.1177/0149206310386228

Hatton, E. (1989). Lévi-Strauss's Bricolage and Theorizing Teachers' Work. Anthropology \& Education Quarterly, 20(2), 74-96. https://doi.org/10.1525/aeq.1989.20.2.05x0841i

Hebdige, D. (1995). Subculture: The Meaning of Style. Critical Quarterly, 37(2), 120-124. https://doi.org/10.1111/j.1467-8705.1995.tb01063.x

Hills, G. E. (1995). Opportunity Recognition by Successful Entrepreneurs: A Pilot Study. Frontiers of Entrepreneurship Research, 105-117.

Hirabayashi, J., \& Kasai, K. I. (1993). The family of metazoan metal-independent $\beta$-galactoside-binding lectins: Structure, function and molecular evolution. Glycobiology, 3(4), 297-304. https://doi.org/10.1093/glycob/3.4.297

Hooi, H. C., Ahmad, N. H., Amran, A., \& Rahman, S. A. (2016). The functional role of entrepreneurial orientation and entrepreneurial bricolage in ensuring sustainable entrepreneurship. Management Research Review, 39(12), 1616-1638. 
https://doi.org/10.1108/MRR-06-2015-0144

Hull, J. (1997). Introduction to Futures and Options. In Introduction to Futures and Options. https://doi.org/10.1016/c2013-0-17600-3

Hurley, R. F., \& Hult, G. T. M. (1998). Innovation, Market Orientation, and Organizational Learning: An Integration and Empirical Examination. Journal of Marketing, 62(3), 42-54. https://doi.org/10.1177/002224299806200303

Johns, B. L., \& Hogan, W. P. (1961). A THEORY OF THE GROWTH OF THE FIRM. Economic Record, 37(78), 171-182. https://doi.org/10.1111/j.1475-4932.1961.tb01369.x

Kelly, D. (1982). The Neuropsychology of Anxiety: An Enquiry into the Functions of the Septo-Hippocampel System. By Jeffrey A. Gray Oxford University Press. 1982. Pp 548. £27.50. British Journal of Psychiatry, 141(6), 634-634. https://doi.org/10.1017/s000712500011373x

Kincheloe, J. L. (2005). On to the next level: Continuing the conceptualization of the bricolage. Qualitative Inquiry, 11(3), 323-350. https://doi.org/10.1177/1077800405275056

Kirzner, I. M. (1997). Entrepreneurial Discovery and the Competitive Market Process: An Austrian Approach. Journal of Economic Literature, 35(1), 60-85.

Lanzara, G. F. (1999). Between transient constructs and persistent structures: Designing systems in action. Journal of Strategic Information Systems, 8(4), 331-349. https://doi.org/10.1016/S0963-8687(00)00031-7

Lavorgna, G., Patthy, L., \& Boncinelli, E. (2001). Were protein internal repeats formed by $\begin{array}{llll}\text { bricolage? Trends in } \quad \text { Genetics, } & 17(3), & 120-123 .\end{array}$ https://doi.org/10.1016/S0168-9525(00)02207-1

Lévi-Strauss, C. (1966). Levi-Strauss/Weightman: Savage Mind.

Ma, R., Huang, Y. C., \& Shenkar, O. (2011). Social networks and opportunity recognition: A cultural comparison between Taiwan and the United States. Strategic Management Journal, 32(11), 1183-1205. https://doi.org/10.1002/smj.933

Margolis, J. (1984). The savage mind totalizes. Man and World, 17(2), 157-174. https://doi.org/10.1007/BF01248674

Miller, D. (1987). The structural and environmental correlates of business strategy. Strategic Management Journal, 8(1), 55-76. https://doi.org/10.1002/smj.4250080106

Morrissey, L. (2003). "Nostalgeria" and structure, sign, and play in the discourse of the human $\quad$ sciences. Historicizing Theory, 99-111. http://rgu-website.s3.amazonaws.com/wp-content/uploads/2020/05/13212039/Derrida-by-Dr. -S.-Singh-UG-2nd-sem.pdf

Ostrom, A. L., Parasuraman, A., Bowen, D. E., Patrício, L., \& Voss, C. A. (2015). Service 
Research Priorities in a Rapidly Changing Context. Journal of Service Research, 18(2), 127-159. https://doi.org/10.1177/1094670515576315

Paul, R. J. (2005). The Labyrinths of Information: Challenging the Wisdom of Systems. European Journal of Information Systems, 14(5), 524-525. https://doi.org/10.1057/palgrave.ejis.3000587

Phillimore, J., Humphries, R., \& Klaas, F. (2016). Bricolage : potential as a conceptual tool for understanding access to welfare in superdiverse neighbourhoods. In Iris Working Paper Series, 14. https://doi.org/10.13140/RG.2.1.4581.5284

Phillips, J. J. (2016). Handbook of Training Evaluation and Measurement Methods. In Handbook of Training Evaluation and Measurement Methods. https://doi.org/10.4324/9781315757230

Rapport, N. (2014). Social and Cultural Anthropology: The Key Concepts. In Social and Cultural Anthropology: The Key Concepts. https://doi.org/10.4324/9781315766560

Rice, R. E., \& Rogers, E. M. (1980). Reinvention in the Innovation Process. Science Communication, 1(4), 499-514. https://doi.org/10.1177/107554708000100402

Rupp, A. A., Ferne, T., \& Choi, H. (2006). How assessing reading comprehension with multiple-choice questions shapes the construct: A cognitive processing perspective. Language Testing, 23(4), 441-474. https://doi.org/10.1191/02655322061t337oa

Rynes, S. L., \& Trank, C. Q. (1999). Behavioral science in the business school curriculum: Teaching in a changing institutional environment. Academy of Management Review, 24(4), 808-824. https://doi.org/10.5465/AMR.1999.2553255

Schroeder, R. G., Buckman, J., \& Cardozo, R. N. (1996). New value creation: the next development in quality management. White paper, Carlson School of Management, University of Minnesota, Minneapolis.

Sehring, J. (2009). Path dependencies and institutional bricolage in post-Soviet water governance. Water Alternatives, 61-81. http://www.water-alternatives.org/index.php/alldoc/volume2/v2issue1/36-a2-1-5/file

Senyard, J., Baker, T., \& Davidsson, P. (2009). Entrepreneurial bricolage: Towards systematic empirical testing. Frontiers of Entrepreneurship Research, 29(5), 5. https://doi.org/papers://BA75DBD3-74D3-4A2D-AAAC-910414082C6C/Paper/p11746

Senyard, J., Baker, T., Steffens, P., \& Davidsson, P. (2014). Bricolage as a path to innovativeness for resource-constrained new firms. Journal of Product Innovation Management, 31(2), 211-230. https://doi.org/10.1111/jpim.12091

Shane, S. (2000). Prior Knowledge and the Discovery of Entrepreneurial Opportunities. Organization Science, 11(4), 448-469. https://doi.org/10.1287/orsc.11.4.448.14602 
Singh, R., Hills, H., \& Lumpkin, G. T. (1999). Examining the role of self-perceived entrepreneurial alertness in the opportunity recognition process. In 13th UIC/AMA Symposium on Marketing and Entrepreneurship Interface, Nice. https://doi.org/10.5465/apbpp.1999.27600505

Sivathanu, B., \& Pillai, R. (2019). An empirical study on entrepreneurial bricolage behavior for sustainable enterprise performance of startups: Evidence from an emerging economy. Journal of Entrepreneurship in Emerging Economies, 12(1), 34-57. https://doi.org/10.1108/JEEE-01-2019-0009

Spicer, C. D., \& Davis, B. G. (2014). Selective chemical protein modification. In Nature Communications, 5. https://doi.org/10.1038/ncomms5740

Stevenson, H. H., \& Jarillo, J. C. (2007). A paradigm of entrepreneurship: Entrepreneurial management. In Entrepreneurship: Concepts, Theory and Perspective, 11, 155-170. https://doi.org/10.1007/978-3-540-48543-8_7

Tushnet, M. (1999). The Possibilities of Comparative Constitutional Law. Yale Law Journal, 108(6), 1225-1309. https://doi.org/10.2307/797327

Ucbasaran, D., Westhead, P., \& Wright, M. (2009). The extent and nature of opportunity identification by experienced entrepreneurs. Journal of Business Venturing, 24(2), 99-115. https://doi.org/10.1016/j.jbusvent.2008.01.008

Van Burg, E., Podoynitsyna, K., Beck, L., \& Lommelen, T. (2012). Directive deficiencies: How resource constraints direct opportunity identification in SMEs. Journal of Product Innovation Management, $\quad 29(6), \quad 1000-1011$. https://doi.org/10.1111/j.1540-5885.2012.00976.x

Veciana, J. M. (2007). Entrepreneurship as a scientific research programme. In Entrepreneurship: Concepts, Theory and Perspective, pp. 23-71. Springer Berlin Heidelberg. https://doi.org/10.1007/978-3-540-48543-8_2

Wang, C. L., \& Ahmed, P. K. (2004). The development and validation of the organisational innovativeness construct using confirmatory factor analysis. In European Journal of Innovation Management, 7(4), 303-313. https://doi.org/10.1108/14601060410565056

Weick, K. E. (2001). Gapping the Relevance Bridge: Fashions Meet Fundamentals in Management Research. British Journal of Management, 12(s1), S71-S75. https://doi.org/10.1111/1467-8551.12.s1.9

Weinstein, D., \& Weinstein, M. A. (1991). Georg Simmel: Sociological Flâneur Bricoleur. Theory, Culture \& Society, 8(3), 151-168. https://doi.org/10.1177/026327691008003011

Yiu, D. W., Lau, C. M., \& Bruton, G. D. (2007). International venturing by emerging economy firms: The effects of firm capabilities, home country networks, and corporate entrepreneurship. Journal of International Business Studies, 38(4), 519-540. 
https://doi.org/10.1057/palgrave.jibs.8400278

Zahra, S. A. (1993). Environment, corporate entrepreneurship, and financial performance: A taxonomic approach. Journal of Business Venturing, 8(4), 319-340. https://doi.org/10.1016/0883-9026(93)90003-N

\section{Notes}

(1) http://pcjcci.org/chinese-companies-registered-in-pakistan/

\section{Copyright}

Copyright for this article is retained by the author(s), with first publication rights granted to the journal.

This is an open-access article distributed under the terms and conditions of the Creative Commons Attribution license (http://creativecommons.org/licenses/by/4.0/). 